\title{
Investigating Factors that Contribute to Effective Teaching-Learning Practices: EFL/ESL Classroom Context
}

\author{
Rukaia Islam $^{1}$ \\ ${ }^{1}$ Ahsanullah University of Science and Technology, Bangladesh \\ Correspondence: Rukaia Islam, Ahsanullah University of Science and Technology, Bangladesh. E-mail: \\ ruku.eng13@gmail.com
}

Received: February 2, 2017

Accepted: March 4, 2017 Online Published: March 6, 2017

doi: 10.5539/elt.v10n4p15

URL: http://doi.org/10.5539/elt.v10n4p15

\begin{abstract}
This paper seeks to address some key issues, which can influence as well as determine the nature of teaching and learning practices in an ELT classroom directly or indirectly. This paper views an EFL or ESL classroom as a dynamic and multi-dimensional platform open to different interpretations of teaching and learning. Factors like teachers' beliefs, teacher talk, teachers' questioning, diversity and complexity of ELT classroom, classroom values and individual learner differences require thoughtful attention irrespective of teaching methods and approaches. However, these issues are not straight forward, rather inherent in the activities related to classroom interaction and management and demand proper conceptualization by teachers, ELT practitioners and researchers.
\end{abstract}

Keywords: EFL/ESL classroom, contributing factors, effective teaching-learning practices

\section{Introduction}

This paper will focus on some key factors, which can influence as well as shape classroom teaching-learning practices in response to the students' immediate learning situation, and the broader socio-cultural context in which English language teaching and learning takes place. Considering a number of cognitive and social perspectives on L2 classroom interaction and management, these factors aim at revealing 'different assumptions about,and understandings of the nature and overall environment of L2 classroom teaching learning practices as we always bring to our experience frames of interpretation, or schemata' (Erikson, 1986). This paper attempts to evaluate that teachers' understanding and consideration of those factors, which are going to be discussed throughout this paper, can play significant roles in ensuring effective classroom practices.

\section{Teachers' Beliefs, Practices and Role of Metaphors in the Classroom}

Teachers often unconsciously hold a set of beliefs, which directly or indirectly shape the ways they design classroom materials and conduct classroom activities. So, undeniably, classroom activities incorporate respective teacher's beliefs, ideologies, experiences and theoretical knowledge that eventually may lead to effective teaching. As Tudor points out that "teachers should not be considered as skilled technicianswho dutifully realize a given set of procedures in accordance with the directives of a more or less distant authority, rather they are active participants in the creation of classroom realities, and they act in the light of their own beliefs, attitudes and perceptions of the relevant teaching situation" (2001). Williams and Burden argue that teachers need to be aware of 'the unique contribution that each individual brings to the learning situation' (1997). Kagan (1992) describes teacher beliefs as 'tacit, often unconsciously held assumptions about students, classrooms and the academic material to be taught'. Shavelson and Stern (1981) also suggest that 'what teachers say and do in their classroom are governed by what they think and believe and those beliefs serve as a filter through which instructional judgments and decisions are made'. ESL/EFL teachers' prior knowledge, experiences and beliefs work 'as a lens through which they make daily instructional decisions in their classroom lessons' (Richards, 1998). This is also notable that, the beliefs are often derived and influenced by others (e.g., colleagues, teachers trainers, educators, academic researchers, co-researchers and institutional environment) and their practical experiences of success and failure in teaching (Hall, 2011). And there exists a common platform for belief and practice where both can inform each other. Some researchers have noticed mismatches between teachers' beliefs and classroom practices having influenced by contextual and institutional factors. 
However, many teachers are not consciously aware of the beliefs and principles that they should follow in conducting a successful language classroom (Farrell, 2015). Metaphor analysis, therefore, can be an influential method to make teachers more aware of their prior knowledge, beliefs and assumptions of teaching that lead to effective classroom management. Through examining the teaching metaphors, ESL/EFL teachers can get more clear insights and self-understanding of what role they should have as language teachers. Lakoff and Johnson (1980) have noted that 'A large part of self-understanding is the search for appropriate personal metaphors that make sense of our lives' (pp. 232-233). So, analysis of the phrase like 'a teacher is a.... (e.g. facilitator or dictator )' can be used as a powerful reflective tool for providing meanings that underpin teachers' work (Farrell, 2015). L2 classroom teaching-learning practices and interaction has been conceptualized through a variety of metaphors, for example, the classroom 'as a controlled platform, as communication, as discourse, as socialization, and as an ecological system' (Breen, 2001a; Tudor, 2001; Wright, 2005). Each metaphor embodies and explains the classroom in different ways, like, 'classroom as socialization' implies that ELT classrooms should have some norms and values to which students conform. Tudor (2001) thinks that L2 classrooms develop their own social rules. According to Breen (2001a), "if we look into another metaphor 'classroom as discourse', the idea of discourse implies that the surface 'text' of a class, what teachers and learners say and do during lessons, can provide insights into L2 teaching and learning, for example, patterns of classroom talk, interaction, and control". So, classroom as 'socialization' and 'discourse' make this clear that different metaphors emphasize different aspects of classroom life. And thus, many of us may easily accept both the insights as valid and valuable.Classroom as a 'controlled learning environment' (Tudor, 2001) is perhaps the most traditional and widespread metaphor for L2 classroom, which has also been termed as 'experimental laboratory' (Breen, 2001a). Several studies have attempted to collate different sets of beliefs and ideologies that are most likely to guide the characteristics and actions of teachers to lead to effective teaching (Williams \& Burden, 1997). As from practical classroom situation we know that each classroom is unique and complex, so what teachers' classroom behavior and activities will obviously vary according to their personal understandings, beliefs, contextual backgrounds, and learner needs and their socio-cultural backgrounds. So portraying and characterizing a 'good teacher' and an 'ideal classroom' is essentially unrealistic. Though in practice, teaching itself is a diverse profession, yet teachers can work for their professional development through exploration and reflection upon their classroom beliefs, practices and the roles that they assume within classrooms through careful metaphor analysis.

\section{Diversity and Complexity of ELT Classroom}

Hall, G. (2011) believes that 'teaching is conceptualized through the transmission of knowledge from teachers to learners and provision of opportunities for learners to discover and construct the knowledge for themselves'. Social and pedagogic character of ELT classroom tends to inform that diversity and complexity are fundamental elements of language teaching and learning, and of language classrooms (Tudor, 2001). Graham Hall (2011) notes that 'what goes on in a classroom is much more than the tidy and logical application of theory and principles rather localized, situation-specific, and, therefore, diverse'. Tudor considers classrooms as social environments (2001) where classroom lessons work as social events being directed by social relationships and social interaction (Erikson, 1986; Allwright, 1989). Widdowson (2003) characterizes the classroom as 'social space' and both he and Wright (2005) recognize that teachers need to balance both social and pedagogic purposes within their classroom behaviour. Widdowson (2003) suggests that teachers are obliged to function as representatives of institutions and society, leading to clear, fixed and hierarchical relationships in the classroom between teachers and students; but teachers also engage in more pedagogically oriented relationships with learners. It has been observed that teachers' decision-making and behavior is constrained by personal philosophy, space, time and available resources, interpersonal and institutional factors, community considerations, syllabus and assessment, and classroom routine (Lynch, 1996). A popular notion is that education is something carried out by one person, a teacher, standing in front of a class and transmitting information to a group of learners who are all willing to receive it. This view, however, simplifies what is a highly complex process involving an intricate interplay between the learning process itself, the teachers' intentions and actions, the individual personalities of the learners, their culture and background, the learning environment and a host of other variables. (Williams \& Burden, 1997).

A global community of English language teachers and learners has been formed with a wide range of social contextual differences around the world. Having highly influenced and guided by classroom context, interactions between teachers and learners can affect the nature and quality of language learning and therefore can make changes in teaching methods and classroom activities. Contexts outside classroom embody a world full of personal and social experiences, which have determining effects on what happens inside classroom. Social conditions (i, e; gender, financial status, class, race, power, and overall priorities of the social world outside the 
classroom) can have effects on learners' performance and the effectiveness of classroom learning. Students' overall performance in language learning is directly or indirectly related to the socio-cultural factors and learners' self-perceptions of their identities as learners of English.From a broader perspective language learning is not just some systematic processes; it involves learners, learners' characteristics, teachers' beliefs and ideology, diverse and complex socio-cultural contexts of classroom; and a balanced co-ordination among all of those can ensure a quality classroom environment committed for effective teaching-learning practices. However, having experienced the wider range of diverse and complex classroom environments, ELT teachers 'aspire to make the right choice at the right time' (Van Lier, 2000) in terms of classroom decision-making and practice.

\section{Teacher Talk and Teachers' Questioning in EFL/ESL Classroom Interaction and Management}

How teachers talk and how they talk to learners is a key element in organizing classroom activities and facilitating learning (Graham, 2001). This is particularly important in an L2 classroom where the medium of instruction is also lesson content, that is language is both the 'vehicle and object of instruction' (Long, M. 1983b: 9) unlike other subjects e.g., physics or geography where lesson content differ with the language used as the medium of instruction. Typically, communication and interaction-based approaches to ELT suggest to minimizing the use of teacher talk in the classroom, thereby providing opportunities for learners to talk, to practice and to produce language. Despite the prevalence of communicative language teaching (CLT), task-based approaches and learner-centered approach within ELT, teachertalk retains a major percentage of time inside L2 classrooms. It has been estimated that over 60 percent of class time is typically given over to teacher talk in some bilingual and immersion classes (Chaudron, 1988). Teacher talk can simply be defined as the language used by the teachers in L2 classroom to convey information to learners as well as to conduct the essential communication with them. To make the concept more simplified this term can also be described as the language teachers typically use in L2 classrooms. As learners also require teacher talk as language input and the most important tool for communication, teachers need to be cautious about not only the quantity of teacher talk but also the quality of teacher talk indeed. The balance of teacher talking time and student talking time inside classroom has always placed an open table for debate and discussion. Teachers' multi-dimensional role in classroom and their beliefs about language learning pattern and style of L2 learners may affect the amount and quality of teacher talk learners are exposed to (Hall, 2001).There is noticeable ambiguity in deciding how teachers should approach 'teacher talk' in L2 classroom. Van Lier (2001) observes that "Teacher talk has been lauded for being comprehensible and criticized for being authentic and not attuned to student needs. Learner talk has been lauded for providing opportunities for negotiating meaning and criticized for being a defective model, riddled with inaccuracies."Though research in light of recent communicative approaches to language learning generally supports the view that 'learner talk' facilitates L2 learning more effectively than 'teacher talk', teachers are always expected to initiate talk as communication tasks (e.g. conversations, dialogues) and to act as facilitators through providing students with useful words, phrases, and even necessary correction in sentence construction. Furthermore, teacher talk might entail the amount of learner talk required on the basis of the task or activities supposed to be conducted in the classroom and that particular classroom context in which learning occurs. So, the point here to be noted is that teachers have their own localized insights to rationalize interactional decisions they take in the classrooms (Walsh,2006b:139) and at the same time their insights as to what kind of talk best facilitates L2 learning will vary according to the context (Hall, 2011). The IRF (Initiation-response-follow-up) exchange can be another pedagogical concept to talk about teacher talk in a L2 classroom. Generally the IRF exchange is associated with teacher-centered classroom interaction (Cullen, 2002). Cullen (2002) exemplifies IRF exchange as a 'powerful pedagogic device' in the interaction based and communicative L2 classroom highlighting the third part of the exchange, ' $F$ ' (follow-up). He thinks the final part is important if that includes discoursal follow-up as well as evaluative feedback. 
Initiation - Response - Follow-up (IRF) circle

T: What would you do if you saw a rob
L: I'd shout (Response)
T: You'd shout...Aaargh!...Laughter
(Follow-up)
$\frac{\text { Analysis of F-move }}{\text { You'd shout }}$
Aaargh...... Repetition
$\begin{aligned} & \text { I don't know if } \\ & \text { the police would } \\ & \text { hear you ! }\end{aligned}$

Figure 1. Source: Adapted from Cullen 2002:123, Cited in Graham Hall (2011);Exploring English Language Teaching: Language in Action.

Learner talk and meanings can be clarified to contribute to usual classroom interaction through follow-up mechanisms such as repetition, elaboration, comment orresponding meaningfully to learner responses (Cullen, 2002). Similarly, researchers have studied on multi-functional roles of Teachers' questioning in classroom interaction. Questions that are particularly asked by the teachers and answered by the learners usually tend to dominate the larger portion of classroom interaction (Hall, 2011), which is approximately estimated 20-40 percent of classroom-talk (Chaudron, 1988). In another study Tsui (1995) had came up with the result that almost 70 percent of classroom interaction could be accounted for by the teacher asking a question, a learner or learners' responding and teachers' feedback to the response (i.e.,initiation-response-feedback exchange). Sinclair and Coulthard (1975), Cook (2008) have supported this figure in their respective studies. Classroom questions are articulated mainly to elicit information from the students, to check students' knowledge and understanding, and specifically for further clarification of the topic discussed by the teacher.Thus, even in a communication-based or meaning-focused setting, IRF exchanges can be employed to intervene in and facilitate comprehension-based learning opportunities when appropriate (Hall, 2011). Taking all these issues into consideration, it can fairly be stated that teacher talk (often in the form of questions) can noticeably contribute to designing effective teaching and learning activities in an EFL/ESL classroom.

\section{Individual Learner Differences in EFL/ESL Classroom}

Individual learner differences can be discussed in terms of learners' contribution to language learning and language classroom. There has been considerable research in exploring the unique relationship between what learners bring to languageclassrooms and the rate and ways in which they learn. In SLA literature, learners' age, personality, aptitude and gender have been popularly termed as learner attributes, which underpin individual learner differences. These are pretty stable characteristics that Graham Hall (2011) thinks that teachers and institutions must attend to and accommodate, but which are not subject to much change (unlike, for example, learner motivation or beliefs which can change over time and which teachers often address). As learners bring differing personalities and attitudes to L2 classroom, teachers often face difficulties in classroom management. Learners also vary in their age, which results in differing individual learner strategies and learning outcomes. So it has been evident that attending to individual learner characteristics is challenging for teachers as learners' age, motivation, beliefs, personality and aptitude can determine how they approach language learning. And consequently, it might not be weird to depict that it is perhaps more interesting to language teachersto note the ways learners vary in conceptualization of learning and L2 classroom and the ways they learn. Thus, justifiably, the ways in which teachers deal with 'who the learners are' might affect classroom performance and overall learners' L2 development.

While examining on the possible influence of individual learners' attributes and attitudes on their L2 learning, it becomes evident that though effective language learning may differ from person to person and context to context, some in-depth explorations of, for example, individual learners' strategies, learning styles, motivation, beliefs, 
autonomy are indicative of learners' control over the construction of their own learning.Allwright and Bailey (1991) highlight a number of areas where learners' social and psychological 'openness' in the classroom might affect learning including receptivity to L2 and its' culture (as explained in acculturation model), classroom practices and norms, course content, teaching materials and language learning activities, the idea of communicating with others and the idea of being a successful language learner. Individual learner differences draw upon the views of language learning that establish the idea that there cannot be a single universal language learning process or experience; learners will learn in differing ways dependent on their social identity and socio-cultural context as a whole.

\section{Culture and EFL/ESLclassroom: Relevance of Acculturation}

According to Brown (2007), second language learning implies 'some degree of learning a second culture' and to some extent, the acquisition of a second identity. Schumann proposed the Acculturation Model in 1978. Schumann in his Acculturation Model suggests that learners need to 'acculturate' that is, they need to adapt to and integrate with, the target language culture; and the extent to which learners acculturate, may define how successful language learning can be. He also points out that learners even need to change their social and psychological behavior in order to get acquainted with the target culture well. So, learners are required to move in to the target language culture socially and psychologically and in this process of acculturation, learners might experience culture shock resulting from a state of having social uncertainty or dissatisfaction when caught between two different cultures one being completely new in most of the cases (Schumann, 1978; Brown, 2007), as they try to get into the differences between their own culture and the target language culture. Adapting to the target culture also involves changes in learner attitudes and motivation (Daniels, 2004). From other perspective, Larsen-Freeman and Long (1991) have highlighted a lot of problems with the theory as they have noticed that there is no reliable way of testing social and psychological distance leading to the need of acculturation.Additionally, several studies have also traced the evidences supporting the view of Ellis (1997), explains the conditions where learners' TL (target language) development is possible despite the fact that learners maintain high social distance with the TL culture.Despite some concerns stated above, acculturation claims the prevalence of some motivational factors that underpin ESL/EFL learning and acknowledges learners' deeper social and psychological needs while learning a TL (Littlewood, 1998). Acculturation model particularly seems to be relevant in ESL/EFL learning contexts as it aims to explain the relationship between 'culture learning' (Brown, 2007) and L2 development in practical contexts where target language might be used regularly. Drawing on Brown's notion of 'identity conflict', that is, 'as language learners take on a new identity with their newly acquired competence' (2007:158), it can be implied that all learners, at some level, might experience alienation from or psychological distance with target language (culture), and values which reminds teachers of need to be sensitive to the 'fragility' of learners (Stevick, 1976). Thus, it is worth mentioning that the concept of acculturation certainly has 'something to say to teaching practitioners' (McLaughlin, 1987, in Hall, 2011).

\section{Values in EFL/ESL Classroom}

In some cases, personal values can determine the effectiveness of classroom practices. Evidently, teachers are not the only source of values in L2 classroom; learners' values also affect classroom life (Hall, 2011). Although values inform classroom behavior, most of the ELT teachers would not agree that they teach values and morality in the classroom, nor would they think that it is their role to do. But, somehow, language teachers tend to guide the students to do the right thing, which ultimately constitutes a major portion of classroom behavior. As it is viewed from Crookes' statement that 'even when morals are not being taught explicitly, schools and teachers are generally trying to do the right thing by their students, and thus they have in a technical sense a moral life, and may, like it or not, be seen as exemplifying one' (2003). Dewey (1909) has also stated that 'teachers teach values as much by what they do as what they say'. However, there are of course some basic values that tend to be common and expected across cultures and educational settings. For example, teachers can incorporate the concepts like sharing with each other, being polite and respectful to learners and teachers, taking care of conversational maxims, turn-taking into classroom teaching-learning practices. So, sense of having personal ideological and moral values which teachers and learners inform each other and share in the classroom, can build a supportive environment for teaching and learning as well.

\section{Conclusion and Evaluation}

Above all, the discussion throughout this paper has placed English language teaching-learning practices within a broader socio-cultural context, essentially entailing the pedagogic characteristics of an EFL/ESL classroom. Although not all the issues presented and discussed in this paper might be of interest to the ELT professionals and experts, the classroom factors investigated and described above undoubtedly have influential impacts on 
what we plan to implement in EFL/ESL teaching-learning contexts and how we maximize the learning outcome. Analysis and investigation of some EFL/ESL classroom factors, thus, led to the realization that teachers' thoughtful observation and proper conceptualization of those can ensure effective English language teaching-learning practices.

\section{References}

Allwright, D. (1989). Language Learning through Communication Practice. In C. Brumfit, \& K. Johnson (Eds.), The Communicative Approach to Language Teaching. Oxford OUP.

Allwright, D. (1980). Turns, Topics and Tasks': Patterns of participation in language learning and teaching. In D. Larsen-Freeman (Ed.), Discourse analysis in second language research

Alright, D. (1989). Interaction in the language classroom: Social Problems and Pedagogical Possibilities.

Allwright, D. (1992). Making Sense of Classroom Language Learning'.Unpublished Ph.D. thesis, Department of Linguistics, Lancaster University.

Allwright, D. (1996). Social and Pedagogic Pressure in Language Classroom: The Role of Socialization. In H. Coleman (Ed.), Society and The Language Classroom. Cambridge: CUP.

Allwright, D., \& Bailey, K. (1991). Focus on The Language Classroom. Cambridge : CUP

Breen, M (1998). Navigating the Discourse: On What is learned in the Language Classroom. In W. Renandya, \& G. Jacobs (Eds.), Learners and Language Learning Anthology Series 39.

Breen, M. (2001a). The Social Context for Language Learning: A Neglected Situation. In C. Candlin, \& N. Mercer (Eds.), English Language Teaching in its Social Context. London: Routledge.

Breen, M. (2001b). Learner contributions to language learning. Harlow: longman.

Brown, H. (2001) Teaching by Principles: An interactive Approach to Language Pedagogy (2 ${ }^{\text {nd }}$ edition). New York: Longman.

Brown, H. (2007). Principles of Language learning and teaching ( $5^{\text {th }}$ edition). New York: Longman.

Cullen, R. (2002). Supportive Teacher talk: The Importance of the F-move'. ELT Journal, 56(2), 117-27. https://doi.org/10.1093/elt/56.2.117

Crookes, G. (2003). A Practicum in TESOL: Professional Development through Language Teaching. Cambridge: CUP.

Crookes, G. (2009). Values, Philosophies and Beliefs in TESOL: Making a Statement. Cambridge: CUP.

Ehrman, M. (2008). Personality and Good Language Learners. In C. Griffiths (Ed.), Lessons from Good Language Learners. Cambridge: CUP. https://doi.org/10.1017/CBO9780511497667.007

Farrell, S. C. (2016). The Teacher is a Facilitator: Reflecting on ESL teacher beliefs through metaphor analysis. IJLTR 2/1, 1-10

Hall, G. (2011). Exploring English language Teaching: Language in Action. London: Routledge. https://doi.org/10.1093/elt/ccq075

Larsen-Freeman, D. (2001). Individual Cognitive/Affective Learner Contributions and Differential Success in Second Language Acquisition. In M. Breen (Ed.), Learner Contributions to Language Learning. Harlow: Longman.

Littlewood, W. (1998). Foreign and Second Language Learning. Cambridge: CUP.

Lakoff, G., \& Johnson, M. (1980). Metaphors We Live By. Chicago/London: Chicago University Press.

Lynch, T. (1996). Communication in the Language Classroom. Oxford: OUP.

Long, M. (2007). Problems in SLA. New York: Routledge.

McLaughlin, B. (1987). Theories of Second language Learning. London: Edward Aronld.

Stern, H. (1983). Fundamental Concepts of Language Teaching. Oxford: OUP.

Stevick, E. (1976). English as an Alien Language, TESOL 76, TESOL Inc.

Stevick, E. (1980). Teaching Languages: A way and Ways. Rowley, MA: Newbury House.

Sinclair, J., \& Coulthard, M. (1975). Towards an analysis of Discourse. Oxford: OUP. 
Schumann, J. (1978). The Pidginization Process: A Model for Second language Acquisition. Rowley, MA: Newbury House.

Tsui, A. (1995). Introducing Classroom Interaction. London: Penguin.

Tudor, I. (2001). The Dynamics of the Language Classroom. Cambridge: CUP.

Van Lier, L. (1988a). The Classroom and the Language Learner. Harlow: Longman.

Van Lier, L. (1996b). Interaction in the Language Curriculum. London: Longman.

Wright, T. (2005). Classroom Management in language Education. Basing-Stoke: Palgrave macmillan. https://doi.org/10.1057/9780230514188

Williams, M., \& Burden, R. (1997). Psychology for Language Teachers. Cambridge: CUP. https://doi.org/10.1177/0261927X970163001

\section{Copyrights}

Copyright for this article is retained by the author(s), with first publication rights granted to the journal.

This is an open-access article distributed under the terms and conditions of the Creative Commons Attribution license (http://creativecommons.org/licenses/by/4.0/). 